\title{
The Rule of Law and the States: A New Interpretation of the Guarantee Clause
}

\begin{abstract}
I therefore apply the term republic to any state that is ruled by laws, whatever the form of government under which this condition obtains. Only in such states does the public interest hold any sway and the public thing have a real existence.
\end{abstract}

-J.J. Rousseau ${ }^{1}$

Although the courts have relegated the guarantee clause ${ }^{2}$ to the nether world of nonjusticiability, ${ }^{3}$ few provisions in the Constitution take us so deeply into the federal structure of the republic or provide so important a clue to the Framers' theories of federalism and representation.

This Note proposes that the guarantee clause should secure the "rule of law"' in the states by requiring, as a matter of federal constitutional law, that the states either observe their own constitutions and laws or change them by legally valid procedures. This interpretation of the guarantee clause fulfills the need for a principled judicial interpretation of the clause previously lacking, and makes sense both as a matter of constitutional law and as a matter of policy. This interpretation of the guarantee clause has important implications for federal/state relations in general and for reapportionment cases in particular.

1. J.J. Rousseav, The Social Contract 39 (W. Kendall trans. 1959).

2. "The United States shall guarantee to every State in this Union a Republican Form of Government . . . ." U.S. Consr. art. IV, § 4, cl. 1.

3. See, e.g., Ohio ex rel. Bryant v. Akron Metropolitan Park Dist., 281 U.S. 74 (1930) (claim that statute delegating certain powers to probate court and unelected federal official violated guarantee clause presented nonjusticiable political question); Ohio ex rel. Davis v. Hildebrant, 241 U.S. 565 (1916) (claim under guarantec clause that invalidation of state reapportionment statute by referendum negates republican government held nonjusticiable); Kiernan v. Portland, 223 U.S. 151 (1912) (guarantee clause claim that municipal charter amendment by initiative and referendum negated republican government held nonjusticiable); Pacific States Tel. \& Tel. Co. v. Oregon, 223 U.S. 118 (1912) (claim under guarantee clause that initiative and referendum violated right to republican government held nonjusticiable since only Congress can enforce clause); Taylor v. Beckham (No. 1), 178 U.S. 548 (1900) (guarantee clause claim that Kentucky's resolution of contested gubernatorial election deprived voters of republican government held nonjusticiable); Luther v. Borden, 48 U.S. (7 How.) 1 (1849) (claim under guarantee clause that popular assembly's proclamation of new government nullified martial law decree of charter government held nonjusticiable).

4. See F. Hayek, The Constrtution of Liberty 133-92 (1960) (rule of law in relation to constitutional government analyzed) [hereinafter cited as CoNSTITUTION OF LibeRTy]; 1 F. HAYEK, LAW, LEGISLATION, AND LIBERTY 1-72 (1973) (historical and theoretical summary of notion of rule of law) [hereinafter cited as LaW, Legislation, and Liberty]; J. Raz, The Authority of LAW 210-29 (1983) (clear exposition of rule of law and its virtues and pitfalls as political ideal); see also infra pp. 566-69 (discussion of idea of rule of law in era of Framers). 


\section{The Confused Jurisprudence of the Guarantee Clause}

Judges and commentators have misinterpreted the history of the guarantee clause, obscured its place in constitutional law, and ignored its policy implications for federalism.

\section{A. Exclusive Congressional Enforcement}

The central guarantee clause cases run from Luther v. Borden ${ }^{5}$ to Baker v. Carr. ${ }^{\circ}$ All suggest the guarantee clause is enforceable only by Congress. In Luther, the Court refused to decide which of two competing governments of Rhode Island was legitimate. ${ }^{7}$ Chief Justice Taney wrote that Congress had exclusive power to decide questions involving the legitimacy of state governments. ${ }^{8}$ Since Congress has the sole power to admit states to the Union under section 3 of article IV and to judge the qualifications of the members of Congress under section 5 of article I, the Chief Justice believed that, by analogy, Congress also had exclusive authority to enforce the guarantee clause. ${ }^{\circ}$

Later Courts accepted Chief Justice Taney's interpretation at face value. In 1912, Chief Justice White construed Luther broadly in Pacific States Telephone \& Telegraph $v$. Oregon, ${ }^{10}$ reading Luther to suggest that the guarantee clause could be used only to nullify the existing government of a state. Chief Justice White thought that the case, which involved a utility company's challenge to a tax law passed by referendum rather than the usual legislative procedure, ${ }^{11}$ presented a political rather than a legal question, ${ }^{12}$ and thus he concluded that the clause was enforceable only by the political branches of government. ${ }^{13}$

\footnotetext{
5. 48 U.S. (7 How.) 1 (1849).

6. 369 U.S. 186 (1962).

7. 48 U.S. (7 How.) at $40-45$. In Luther, the plaintiff challenged the legality of a martial law decree under which the charter government's soldiers had invaded her house. The plaintiff claimed the decree was invalid because the state government issuing it had allegedly been supplanted by a new
} government proclaimed by popular convention.

8. Id. at 39 .

9. Id. at 42-43. Justice Woodbury, however, contributed a thought-provoking partial dissent in Luther which, while it provided compelling reasons for the Court not to adjudicate the legitimacy of a state government, id. at 51 (Woodbury, J., dissenting), argued strongly for the judicial review of the martial law decree to determine its consistency with republican government, id. at 59.

10. 223 U.S. 118 (1912).

11. Id. at 133-34, 137.

12. Id. at $149-50$.

13. Id. at 150-51. The remedy claimed in Luther thus became the exclusive remedy under the guarantee clause. Chief Justice White's reasoning became the foundation of guarantee clause nonjusticiability. See supra note 3 . The most compelling argument for congressional enforcement is found not in Chief Justice Taney's opinion in Luther, however, but rather in Justice Woodbury's dissent. Justice Woodbury argued that the judicial power to decide whether or not the people of a state have successfully changed or replaced their constitution would make the federal court the ultimate sovereign in the state. 48 U.S. at 52 (Woodbury, J., dissenting). Since American constitutionalism proceeds on the assumption of popular sovereignty, only the people can rightfully overrule a constitution estab- 


\section{Guarantee Clause}

In the next important case concerned with the guarantee clause, Baker v. Carr, ${ }^{14}$ Justice Brennan emphasized the Court's past refusal to invalidate state action under the guarantee clause and concluded that the guarantee clause was not judicially enforceable because it lacked standards to guide judicial discretion. ${ }^{15}$ The court held that state legislative reapportionment was justiciable, ${ }^{16}$ but did so under the equal protection clause even though the case presented issues which fell squarely under the guarantee clause. ${ }^{17}$

\section{B. Flaws of Exclusive Congressional Enforcement}

Relegating the enforcement of the guarantee clause exclusively to Congress is problematic for three reasons. First, it violates the premise of Marbury v. Madison ${ }^{18}$ that the Constitution contains judicially discoverable and enforceable principles. ${ }^{10}$ Although some constitutional clauses have been considered nonjusticiable, ${ }^{20}$ this view presents theoretical difficulties. ${ }^{21} \mathrm{~A}$ theory of the guarantee clause allowing principled judicial enforcement is preferable.

lished by the people of a state. Id. at 55. Judges can only interpret, not frame, constitutions. As Justice Woodbury put it, "Our [judicial] power begins after [the people's] ends." Id. at 50; see id. at 52-54. To decide what constitutes a "republican form of government"-what a constitution can permissibly say or what constitutes the official government of a state-is therefore a political question. Id. at 56. This Note does not suggest that courts dictate to the people of the states what their constitutions may say.

Chief Justice White's mistake in Pacific Stales was to assume that the guarantee clause could only be given effect in the fashion requested by the plaintiff in Luther. Chief Justice White extended Chief Justice Taney's reasoning that only Congress could replace one state government with another to forbid all use of judicial power under the clause. John Hart Ely correctly identified this as the error that has vitiated guarantee clause jurisprudence. Sep J. ELY, Democracy and DisTruST 118 n.* (1981). Chief Justice White confused the right with the remedy asked for in Luther.

14. 369 U.S. 186 (1962).

15. Id. at $223-24$.

16. Ill. at 237.

17. Id.

18. 5 U.S. (1 Cranch) 137 (1803).

19. Il. at 166, 177-78; spe also L. Tribe, American Constrtutional Law $\S 3-3$, at 20-23 (1978) (discussing Constitution as containing judicially enforceable principles); Scharpf, Judicial Rezipu and the Political Question: A Funclional Analysis, 75 YALE L.J. 517, 517-19 (1966) (discussing principle in Marbury that Constitution contains judicially enforceable law); Van Alstyne, $A$ Critical Guide to Marbury v. Madison, 1969 Duke L.J. 1 (critical survey of arguments for judicial enforcement of Constitution in Marbury); Wechsler, Tourard Neutral Principles of Constitutional Law, 73 Harv. L. Rev. 1 (1959) (Constitution's status as supreme law).

20. Sep L. TRIBE, supra note 19, § 3-16, at 75-79 (explaining Court's reluctance to enforce clauses pertaining to foreign affairs against executive action). Clauses in the Constitution pertaining to the President's power to make treaties, U.S. Consr. art. II, \& 2, cl. 2, have been held nonjusticiable. Sep Banco Nacional de Cuba v. Sabbatino, 376 U.S. 398, 416 (1964); Chicago \& S. Air Lines v. Waterman S.S. Corp., 333 U.S. 103 (1948); Scharpf, supra note 19, at -538-46 (functional analysis of political question doctrine applied to executive discretion in foreign affairs).

21. Professor Tribe argues that the nonjusticiability of some clauses of the Constitution is consistent with judicial power to interpret and enforce other constitutional clauses, L. TRIBE, supra note 19, $\S 3-16$, at $72-73$, but Tribe is unable to provide a principle for determining which clauses the Court may interpret. Although Tribe attempts to provide such a principle by suggesting that the Court 
Second, the nonjusticiability of the guarantee clause cannot be justified in terms of the political question doctrine. Luther, Pacific States, and Baker all rely on the political question doctrine, in one form or another, to justify the clause's nonjusticiability. ${ }^{22}$ Yet as Justice Brennan stated in Baker v. Carr, the political question doctrine is derived from "the relationship between the judiciary and the coordinate branches of the Federal Government, and not the federal judiciary's relationship to the States ....23 To use the political question doctrine to decide the issues of federalism raised by the guarantee clause is therefore inappropriate.

Third, the incomplete and unsatisfying analysis of the reapportionment cases points to the necessity of reviving the guarantee clause. Justice Frankfurter noted the relevance of the clause when he declared that Baker was a "Guarantee Clause claim masquerading under a different label." Commentators as ideologically different as Bork and Ely have advocated reviving the guarantee clause by suggesting that the reapportionment cases would have been better decided under its authority. ${ }^{25}$ The Court's failure to interpret the guarantee clause over the last two hundred years ${ }^{28}$ has prevented such a development.

The inadequacy of our current understanding of the guarantee clause is in some ways not surprising. No good contemporary theory of federalism exists. This is apparent in the disputes surrounding the Fourteenth Amendment ${ }^{27}$ and the incorporation doctrine. ${ }^{28}$ Because the Framers in-

should not attempt to enforce those clauses which would, if enforced, infringe upon the powers of the other branches or give the Court excessive political power, id., this suggestion merely sacrifices the specific guarantees of the constitutional text to a vague, extra-constitutional notion of what the powers of the Court should be. Moreover, any judicial interpretation of a constitutional clause is in some sense infringement by the Court on the power of the other two branches of government. His approach is therefore at odds with the theory of judicial review found in Marbury, 5 U.S. (1 Cranch) at 177.

22. See Baker v. Carr, 369 U.S. 186, 228 (1962); Pacific States Tel. \& Tel. Co. v. Oregon, 223 U.S. 118, 150 (1912); Luther v. Borden, 48 U.S. (7 How.) 1, 47 (1849).

23. 369 U.S. 186, 210 (1962). For a history of the guarantee clause and the political question doctrine, see Scharpf, supra note 19.

24. 369 U.S. 186, 297 (1962) (Frankfurter, J., dissenting).

25. See Bork, Neutral Principles and Some First Amendment Problems, 47 IND. L.J. 1, 19

(1972); J. Ely, supra note 13, at 118-23. Ely writes:

[I]t seems likely that this unfortunate doctrine-that all Republican Form cases are necessarily cases involving political questions-will wholly pass from the scene one of these days. Friend and foe alike have come to recognize the obvious, that although the various state voting rights cases decided by the Warren and Burger Courts have been styled as equal protection decisions, they cannot comfortably be understood without a strong injection of the view that the right to vote in state elections is a rather special constitutional prerogative, a view that cannot be teased out of the language of equal protection alone and in textual terms is most naturally assignable to the Republican Form Clause.

Id. at 118.

26. See supra note 3.

27. See Trimble v. Gordon, 430 U.S. 762,777 (1977) (Rehnquist, J., dissenting) (equal protection clause jurisprudence incoherent and return to Framers' intentions needed). Ely believes the failure of the Court and commentators to provide a theoretical justification for expanding the equal protection clause strengthens Rehnquist's position. J. ELY, supra note 13, at 149.

28. Compare Adamson v. California, 332 U.S. 46, 71-90 (1947) (Black, J., dissenting) (Four. 


\section{Guarantee Glause}

tended the guarantee clause to be a principal restraint on the states in the original Constitution, ${ }^{29}$ and because the clause goes directly to the relationship between federal and state power, a clear role for the guarantee clause could contribute to a satisfactory theory of federalism.

\section{Federal Guarantee of State Constitutions}

This Note interprets the guarantee clause as requiring the states to adhere to the "rule of law." This doctrine would allow principled judicial enforcement of the guarantee clause, is consistent with constitutional and policy considerations, and leads to a new understanding of the reapportionment cases and of federalism.

\section{A. The Federal Guarantee of the Rule of Law in the States}

The guarantee clause should be read as securing the "rule of law" in the states. ${ }^{30}$ Such an interpretation would require that each state obey its own constitution and statutes, or change those laws by legally valid means. As long as Congress did not invalidate a state's constitutional structure or statutory provisions ${ }^{31}$ as nonrepublican in form, the state constitution would be considered valid. The federal courts would be limited to scrutinizing state actions for their consistency with state constitutions and laws.

Historically, Congress has been the only branch of government to exercise power under the guarantee clause. ${ }^{32}$ Congress would maintain this

teenth Amendment fully incorporates Bill of Rights and thus applies to states) with R. BERGER, GOVERnMFNT BY Judiciary 134-56 (1977) (suggesting Fourteenth Amendment does not fully incorporate Bill of Rights).

29. Sep The Frderat.ist No. 21, at 130-31 (J. Madison) (J. Cooke ed. 1961) (Madison discusses importance of a "guarantee to limit tyranny in the states").

30. See infra note 34 (discussing "rule of law").

31. This Note envisions congressional review of any statute or constitutional amendment passed in a state which affected the state's "form of government." Thus many statutes and other state acts would be outside congressional review. The scope of this review, however, should be determined by Congress. A court should exercise the same deference toward these congressional determinations as it would toward executive acts in foreign affairs; i.e., it should consider them governed by the separation of powers doctrine and thus "political questions."

32. One such exercise of power involved congressional scrutiny of the constitutions of southern states readmitted after the Civil War. See generally W. Wiecek, The Guarantee Clause of the U.S. Constriturion 11-77 (1972) (enforcement of guarantee clause by Congress). For examples of contemporary documents discussing this exercise of the guarantee clause, see CoNG. GLOBE, 40th Cong., 2d Sess. 2465 (1868) (Thaddeus Stevens' remarks on congressional scrutiny of state constitutions for republican form); SEN. ExEc. Doc. No. 57, 40th Cong., 2d Sess. 14-15 (1866) (rigorous congressional scrutiny of constitutions of southern states seeking readmission to Union). In Minor v. Happersett, 88 U.S. (21 Wall.) 162, 176 (1875), the Court stated that the state governments "were accepted precisely as they were, and it is, therefore, ta be presumed that they were [republican in form]." Since Congress has exclusive authority to accept new states into the Union, U.S. CoNST. art. IV, $\S 3, \mathrm{cl} .1$, the Court held it is not for the judiciary to review state constitutions when they have already been accepted. Minor, 88 U.S. (21 Wall.) at 175-76; see also Luther v. Borden, 48 U.S. (7 
central role under this Note's proposal. Congress would thus review the substance of state constitutions ${ }^{83}$ while the courts would exercise only a procedural review. ${ }^{34}$

\section{B. Constitutional Arguments for the Proposal}

This somewhat revolutionary view of the guarantee clause is, in fact, defensible as a matter of constitutional law. Textual arguments, historical arguments, and arguments of structure and relation all provide support. ${ }^{35}$

The text of the guarantee clause reads: "The United States shall guarantee to every State in this Union a Republican Form of Government ...." The use of the "United States" as the subject of the clause is significant since it implies that Congress is not the only branch empowered to enforce the guarantee clause. Elsewhere in the Constitution, powers belonging exclusively to one branch are located in one of the first three articles. ${ }^{37}$ In article IV, the text explicitly refers to Congress four times. ${ }^{38}$ The text of the guarantee clause, however, does not refer to Congress and thus suggests that Congress has no exclusive role in its enforcement.

How.) 1, 42 (1849) (acceptance of state into Union recognition that state's government is republican, i.e., Congress makes substantive evaluation of satisfaction of guarantee clause). For a complete history of Congressional application of the clause, see W. Wiecek, The Guarantee Clause of the U.S. Construtution (1972).

33. See Minor v. Happersett, 88 U.S. (21 Wall.) 162, 175-76 (1975). Sep generally W. WIECEK, supra note 32 (tracing exclusive congressional power under guarantee clause through its history).

34. The procedural theory of the guarantee clause embodied in this Note grows out of the concept of the rule of law. See generally LAW, LEGisLation, AND LiBERTY, supra note 4 (general theoretical exposition of the rule of law); G. STOURzH, Alexander Hamil.ton and the IDEA of Republican GOVERNMENT 45, 56-63 (1970) (idea of republican government contained rule of law as essential element); L. TRIBE, supra note 19, \$10-1, at 474-77 (summarizing rule of law as "model of governmental regularity"). This concept suggests that rulers unconstrained by laws are most likely to be oppressive and to disrespect minority rights. Regular procedures that rulers must follow and that limit their power distinguish lawful action from the mere exercise of force. See generally Constiturion OF LIBERTY, supra note 4, at 162-76 (theoretical exposition and intellectual history of the rule of law); E. Corwin, The "Higher Law" Background of american Constitutional Law 8 (1955) (history of notion that rulers should be subject to law); L. FuLLER, THE MORALITY OF LAw 81-91 (1962) (discussing when official action conflicts with law). In this view, acts of the legislature are as illegal as the acts of a mob or a dictator, unless the law-making body observes the limits spelled out in a written constitution or in some other form. This is the sense in which The Massachuselts Declaration of Right establishes "a government of laws and not of men." See G. STourzH, supra, at 56; see also J. Adams, Novanglus, in 4 The Works of John Adams 100-21 (C. Adams ed. 1851) (constitutional protection and democracy inseparable); 3 The Debates IN the Several State Conventions on THE Adoption of THE Federal. Constitution 39 (1836) (statement of E. Pendleton of Virginia) (equating republican government with "government of laws and not of men"); J.J. Roussenu, supra note 1, at 39 (rule of law essence of republican government); Lee, Letters of $a$ Federal Farmer, in Pamphlets on the Constrtution of the United States 324 (P. Ford ed. 1888) [hereinafter cited as PAMPHLETs]; Webster, An Examination into the Leading Principles of the Federal Constitution, in Pamphlets, supra, at 34.

35. See generally' P. Bobbitr, Constitutional Fate (1982) (examining forms and consequences of various styles of constitutional argument).

36. U.S. Const. art. IV, § 4, cl. 1.

37. Id. at arts. I (legislature), II (executive), III (judiciary).

38. Id. at art. IV, $\S 1$, cl. 1 ; id. at art. IV, $\S 3$, cls. $1,2$. 


\section{Guarantee Clause}

Conceptions of the rule of law permeated the Framers' discussions of republicanism in the Federalist Papers ${ }^{39}$ and elsewhere. ${ }^{40}$ The Framers' shared definition of tyranny was government that did not operate according to the regular procedures established by the law. ${ }^{41}$ This view was central to the Framers' "Whig science of politics." 42 It explains their resistance to Parliament's illegal acts and their efforts to limit the legislative power of the states and, later, of Congress. The Framers' fear of arbitrary power led to a preoccupation with procedural regularity and with the limitations on official authority provided by law. ${ }^{43}$ The Framers saw

39. Tribe describes the history of the rule of law as a "persistent war . . . against capricious subjugation to the whim of the sovereign ... . Arbitrary power . . . is not law, whether manifested as the decree of a personal monarch or an impersonal multitude." Sep L. TRIBE, supra note $19, \S 10$ 1 , at 474-76. The articulation of laws must proceed through general law-making processes accountable to the electorate, at one end of the spectrum, and be answerable to the individuals at the other end of the spectrum on whom these processes operate. Id.

These themes emerge repeatedly in the Federalist Papers. See, e.g., The Federalist No. 9, at 50-51 (A. Hamilton) (J. Cooke ed. 1961) (need to protect republics against tyranny and anarchy; efficacy of "regular distribution of power into distinct departments," legislative checks, independent courts, popularly elected legislatures, to this end); id. No. 10, at 57 ( $\mathrm{J}$. Madison); see also id. No. 48, at 335-36 ( $\mathrm{J}$. Madison) (criticizing state legislatures for adjudicating rights that should have been determined in judicial procedures, and for other abuses of legal process).

The Federalist No. 21 contains a striking discussion by Hamilton of the guarantee clause that weaves together rule of law themes and the necessity of the clause:

The want of a mutual guarantee of the State governments is another capital imperfection in the federal plan....

Without a guarantec, the assistance to be derived from the Union in repelling those domestic dangers, which may sometimes threaten the existence of the State constilutions, must be renounced. Usurpation may rear its crest in each State, and trample upon the liberties of the people; while the national government could legally do nothing more than behold its encroachments with indignation and regret .... [A federal guarantee of state constitutions] could be no impediment to reforms of the State Constitutions by a majority of the people in a legal and peaceable mode. This right would remain undiminished. The guarantee could only operate against changes to be effected by violence. . . . A guarantee by the national authority would be as much levelled against the usurpations of rulers, as against the fennents and outrages of faction and sedition in the community.

Id. at 130-32 (A. Hamilton) (emphasis added).

Hamilton's argument for a "guarantee" clause strongly supports this Note's interpretation. It is clear that, for Hamilton, the "usurpations of rulers" against the "State constitutions" would violate such a guarantee.

40. See, e.g., J. AdAms, Thoughts on Government, in 4 Works of JoHn ADams, supra note 34, at 194; Letter from Samuel Adams to James Warren (January 16, 1777), reprinted in 3 THE WRITIngs of Samuel. Adams 347-48 ( $\mathrm{H}$. Cushing ed. 1904); T. Jefferson, 1 Jefrerson Papers 119-37, 329-85, 429-32 (J. Boyd ed. 1950); J. Wilson, Lectures on Law, in 1 Works OF JAMES Wilson (H. McCloskey ed. 1967). See generally G. WOOD, The CREATION of THE AMERICAN REPuBLIC 1776-1787 (1969) (intellectual history of American Constitution).

41. In his "Tully" essays, Alexander Hamilton expounded on the importance of the rule of law to republican government: "Government is frequently and aptly classed under two descriptions-a govcrnment of FORCE, and a government of LAWS; the first is the definition of despotism-the last, of liberty." A. Hamilton, Tully, in 6 Works of Alexander Hamilton 419 (H. Lodge ed. 1904).

42. G. Woon, supra note 40, at 3--45 ("The Whig Science of Politics"); see id. at 519-64 (describing application of ideas of "Whig Science of Politics" to framing of institutions of American government). See generally B. Bailyn, The Ideological. Origins of the American Revolution 55-93 (1967) (summarizing "Whig" politics of Framers).

43. The "spirit of Whiggism," as Hamilton called it, "reprobates equally the punishment of the citizen by arbitrary acts of the legislature, as by the lawless combinations of unauthorized individu- 
the state constitutions as different means to this same end of securing the rule of law. ${ }^{44}$

James Madison noted that among the "Vices of the Political System of the U. States" under the Articles of Confederation was the absence of a "guaranty to the states of their Constitutions and laws against internal violence."45 Madison's fear that mobs and corrupt officials would violate state constitutions underscored his commitment to government by lawful procedures, and his explanation of republican theory to the Constitutional Convention emphasized that lawful rule would collapse if minorities had overwhelming military power or if the majority had insufficient access to the legislature because of limited franchise. ${ }^{48}$ Indeed, one of Madison's early drafts of the guarantee clause provided that the United States would guarantee the "constitutional authority" of the states. ${ }^{47}$ This version of the guarantee clause was ultimately rejected because the Framers feared it would prevent the states from amending or replacing their own constitutions. ${ }^{48}$ James Wilson met this objection by providing the language that

als." A. Hamilton, Letter from Phocion, in 3 The Papers of Alexander Hamilton 484 (1961). John Adams noted that "a government in which all men, . . . magistrates and subjects, officers and people . . . are equally subject to the laws . . appears to be the true and only true definition of a republic." J. ADAmS, Defence of the Constitutions of Govermment of the United States of America, in 5 WORKs OF JOHN ADAMS, supra note 34 , at 453.

The core meaning of the guarantee clause is therefore not merely the proscription of aristocratic and monarchical government. But see Bork, supra note 25, at 19 (vacillating between broad and narrow reading of the guarantee clause). There is, however, a long tradition of equating republican government with government by the people, though not with that principle in isolation. See G. STOuRzH, supra note 34, at 48-56; G. Wood, supra note 40, at 63, 345-54, 363-89, 530-36; cf. A. Bickel, THE Supreme Court and THE IDeA of Progress 110 (1970) (contrasting republicanism of Framers with simple "populist majoritarianism" of reapportionment cases).

The republicanism of the Framers had at least two essential features: government by the people and the rule of law. This Note attempts to preserve both features by giving both Congress and the courts a role in enforcing the clause, and by allowing the people of a state to frame their own constitutions but requiring those constitutions to be enforced according to the rule of law. The Framers viewed state constitutions as fundamental law in the same sense as the U.S. Constitution. See G. WILLS, ExPLAINING America: The Federalist 152-55 (1981) (Madison's views on judicial review in proposed Kentucky constitution).

44. John Adams wrote that the great question of his day was "what combination of powers in society, or what form of government, [would] compel the formation, impartial execution and faithful interpretation of good and equal laws." J. ADAMS, A Defence of the Constitutions of Got'ernment of the United Slates of America, in 4 Works OF JoHN ADAMS, supra note 34, at 406 . Indeed, even the participation of the people in government had been justified by arguing that such participation alone could prevent lawlessness, a view most elegantly summarized in J.S. MILl, On Liberty, in EsseNTIAL Works of John Stuart Mili. 256-57 (M. Lerner ed. 1961). See also J. Adams, Nozianglus, in 4 WORKS OF JoHN ADAMS, supra note 34, at 80 (importance of rule of law to preservation of liberty); A. Hamilton, supra note 43, at 545 (criticizing irregularity in legislative procedure); R. PRICE, Observations on THE Nature of Civil Liberty 3 (1778) (connection of rule of law to civil liberty).

45. J. Madison, Vices of the Political System of the $U$. States, in The Mind of The Founder 85 (M. Meyers ed. 1981).

46. Id. at 107 (Madison's speech of June 19, 1784, to Constitutional Convention).

47. W. WIECEK, supra note 32 , at 57 .

48. Id. at $50-70$. 


\section{Guarantee Glause}

was finally adopted, which allowed states to alter their constitutions so long as they did not deviate from accepted republican principles. ${ }^{49}$ The amendment was not viewed as limiting the significance of the clause; it was understood throughout the debate that the guarantee clause was meant to accomplish the crucial goal of ensuring legal government in the states. $^{\text {so }}$

The rule of law interpretation of the guarantee clause can also be supported by arguments of constitutional structure and relation. ${ }^{\text {51 }}$ In particular, there is an analogy between the guarantee clause protection and some of the other protections secured by article IV and the Fourteenth Amendment.

In both the full faith and credit clause ${ }^{62}$ and the privileges and immunities clause ${ }^{83}$ of article IV, a federal right derives its content from the constitution and laws of the state in which it is applied. Under the full faith and credit clause, a state may not act to frustrate the "procedural due process" rights created by another state's constitution and laws. A citizen therefore has a federal constitutional right to have the legal processes of his own state protected from infringement by every other state. Similarly, the privileges and immunities clause ensures that a citizen of a state who ventures into another state enjoys the same privileges and immunities enjoyed by the citizens of the host state. Under both these clauses, then, a citizen has a federal guarantee to rights whose content derives from another state's constitution and laws. This Note argues that a citizen has an analogous federal claim under the guarantee clause against actions by his own state if they violate his own state's constitution and laws.

The rule of law interpretation of the guarantee clause can also be supported by analogy to the Fourteenth Amendment. The due process clause

49. Id. at 59 .

50. Id. at 59, 76-77. In The Federalist No. 43, Madison justifies these separate parts of section four by quoting from the classical republican theorist Montesquieu. Montesquieu argued that an important advantage of a federal republic is "that should a popular insurrection happen in one of the States, the others are able to quell it. Should abuses creep into one part, they are reformed by those that remain sound." The Federalist No. 43, at 91 (J. Madison) (J. Cooke ed. 1961) (quoting Montesquieu, The SpIRIT or Laws 185 (2d ed. 1752)). Montesquieu's language illustrates the two concerns of section 4 of article IV: The protection clauses provide for federal intervention against the threat of armed force, while the guarantee clause provides protection against "abuses" which may "creep into one part" of the Union. Such "creeping" abuses might come in the form of state action in violation of the states' constitutions and laws. Both "creeping" abuses and invasion or insurrection threaten the rule of law, the former by allowing contempt for observance of legal procedure and the latter by allowing oppressive regimes to come to power.

51. See genetally C. Black, Structure and Relationship in Constitutional Law (1969) (constitutional interpretation should take place within whole context of legal and political structures and relationships set up by Constitution).

52. "Full Faith and Credit shall be given in each state to the public Acts, Records, and judicial Proceedings of every other State." U.S. CoNST. art. IV, § 1, cl. 1 .

53. "The Citizens of each State shall be entitled to all Privileges and Immunities of Citizens in the several States." U.S. CoNST. art. IV, $\$ 2$, cl. 1. 
of that amendment ${ }^{54}$ protects against arbitrary and capricious action by state officials and legislatures. ${ }^{.5}$ In that respect, the guarantee afforded by the due process clause is similar to that afforded by the rule of law interpretation of the guarantee clause. ${ }^{58}$ The Fourteenth Amendment's equal protection clause ${ }^{87}$ prohibits arbitrary classifications by state legislatures. ${ }^{68}$ One requirement of the rule of law is that legislative classifications be sufficiently general. ${ }^{59}$ Equal protection reflects that requirement and thus imposes the rule of law on the states.

The analogies between the Fourteenth Amendment and the guarantee clause are reassuring for two reasons. The equal protection and due process clauses of the Fourteenth Amendment have been the chief restraint imposed by the federal government on state power, and thus the rule of law outlook, to the extent it is similar, is consistent with important consti-

54. "No State shall ... . deprive any person of life, liberty, or property, without due process of law . . . . U.S. Const. amend. XIV, \& 1 .

55. See, e.g., Benton v. Maryland, 395 U.S. 784 (1969) (double jeopardy prohibition applied to states); Wolf v. Colorado, 338 U.S. 25 (1949) (privacy protected against arbitrary state police action). For a summary of possible judicial responses to arbitrary and capricious state action, see Kadish, Methodology and Criteria in Due Process Adjudication-A Survey and Criticism, 66 Yale. L.J. 319 (1957).

56. Although violations of the rule of law would seem classically arbitrary and capricious, the Court has never held them so. As Ely has observed, however, there is a distinct meaning of due process as the rule of law, namely, that governments deal with citizens only in accordance with a process of law. See J. ELY, supra note 13, at $189 \mathrm{n} .13$. This meaning accords with the argument of this Note. Justice Black expressed a willingness to add this sort of requirement to his incorporation interpretation: "For me the only correct meaning of [due process of law] is that our Government must proceed according to ... written constitutional and statutory provisions as interpreted by court decisions." In re Winship, 397 U.S. 358, 382 (1970) (Black, J., dissenting) (emphasis added). Ely finds it "difficult to believe [Justice Black] was serious about this, since it would make every question of state law a federal question." J. ELY, supra note 13, at 189 n.13. Of course, this Note proposes precisely that the obedience to the rule of law suggested by Black be required of the states under the guarantee clause, though the scope of judicial review it suggests is limited, see infra p. 579.

57. "No State shall ... deny to any person within its jurisdiction the equal protection of the laws." U.S. ConsT. amend. XIV, § 1.

58. It may have been more generally intended to protect against arbitrary and capricious acts by state legislatures. See generally J. ELY, supra note 13, at 131 (analyzing equal protection clause jurisprudence in terms of forcing articulation of legislative motives).

59. See generally ConstrTuTION OF LIBERTY, supra note 4, at 1-72 (general theoretical exposition of rule of law in which generality of law is consistent theme). The remedial powers of Congress under the guarantee clause also resemble those under the standard enforcement clause of the Fourteenth Amendment, which includes special powers to enforce the Fourteenth Amendment against the states. See Fullilove v. Klutznick, 498 U.S. 448 (1980) (Congress has special power to enforce Fourteenth Amendment under section five of that amendment); Katzenbach v. Morgan, 384 U.S. 641 (1966) (same). This power is similar to the special enforcement power that Congress has been held to possess under the guarantee clause. See Pacific States Tel. \& Tel. Co. v. Oregon, 223 U.S. 118 (1912).

In both instances, Congress could legislate a change in the way in which a state is governed. Congress did exactly that when it used its powers under the Fourteenth Amendment to regulate the manner in which states could conduct elections with the Voting Rights Act of 1965, Pub. L. No. 89. 110, 79 Stat. 437 (codified as amended at 42 U.S.C. $\$ \S 1971,1973$ to 1973bb-1 (1976)). Congress's power to enact the Voting Rights Act is supported by the guarantee clause as well as by section five of the Fourteenth Amendment. Both clauses give Congress enormous power to alter the substantive form of a state government. 
tutional values. Second, the analogies suggest that this Note's interpretation of the guarantee clause is less radical than it first appears, since it builds on Fourteenth Amendment values.

\section{The Madisonian Argument for Rule of Law in the States}

The tenets of Madisonian theory also imply that a rule of law interpretation will best prevent tyranny by state governments. Madison believed that lawlessness was more likely at the state than at the federal level of government. In addition, he was obsessed with the problem of how to reconcile the principle of majority rule with the protection of minority rights. These two fears, combined with Madison's empirical judgment that small political units would tend to be controlled by stable majority coalitions which would be likely to violate minorities' rights, ${ }^{\text {eo }}$ led Madison to advocate a large republic as the best form of government for the United States. He believed that large republics would be more likely than the states to protect minority rights for two reasons. First, in a large republic, the great variety of shifting and conflicting interests would make it more difficult for a permanent majority coalition to form. ${ }^{61}$ Large republics would better protect minority rights than small ones because larger and more geographically dispersed polities would possess more numerous and various interest groups.

Second, Madison recognized that members of a potential national majority coalition would, in modern parlance, encounter prohibitive organizational costs because of their number." "Discrete and insular minorities,"es by contrast, face relatively low organizational costs because of their small size. ${ }^{84}$ Minorities may therefore expect to have, at the national level,

60. The Federalist No. 10, at 61-64 (J. Madison) (J. Cooke ed. 1961).

61. Madison wrote:

[T] he greater number of citizens and extent of territory which may be brought within the compass of republican than of democratic government . . . renders factious combinations less to be dreaded in the former than in the latter. The smaller the society, the fewer probably will be the distinct parties and interests composing it; the fewer the distinct parties and interests, the more frequently will a majority be found of the same party . . . Extend the sphere and you take in a greater variety of parties and interests; you make it less probable that a majority of the whole will have a common motive to invade the rights of other citizens . . .

Id. at 63.

62. Madison wrote:

Extend the sphere... [and] you make it . . more difficult for all who feel it to discover their own strength and to act in unison with each other. Besides other impediments, it may be remarked, that where there is a consciousness of unjust or dishonorable purposes, communication is always checked by distrust, in proportion to the number whose concurrence is necessary.

Id. at 63-64. Large groups are thus more difficult to organize, first, because large groups find it difficult to formulate a common purpose, and second, because the larger the group, the costlier is organization and communication. See M. Olson, The Logic of Collective ACTION 53-65 (1971).

63. See United States v. Carolene Prods. Co., 304 U.S. 144, 152 n.4 (1938) (origin of "discrete and insular minority" analysis).

64. M. Olson, supra note 62, at 53-65. This Note's analysis draws on that of Note, $A$ Madis- 
an influence disproportionate to their numbers. At the state level, however, minorities would face majorities that could more easily organize. Thus minorities within a state would be especially vulnerable to abuse by majority factions.

State constitutions were therefore, in Madison's view, an important line of defense against abusive majorities. Madison believed that state constitutions had been framed when the American continent was relatively unsettled and circumstances were therefore especially propitious for the protection of minority liberties. A state's early history was usually characterized by an abundance of resources that made all individuals, at least in their own view, potential members of the propertied class. Each citizen thus had an interest in framing a constitution that protected property rights, which to Madison were synonymous with minority rights. ${ }^{\circ 5}$ As the state developed and property inevitably became more concentrated, however, this propitious moment passed. It was therefore important to preserve and enforce constitutions framed before interests became well defined and antagonistic if minority rights were to be protected. ${ }^{86}$

We may better understand the force of Madison's insight by comparing it to John Rawls's notion of an "original condition" in which fair constitutions are framed. ${ }^{67}$ In Rawls's theory, the "constitution" that individuals frame is fair because they make their decisions under special conditions uniquely favorable to the preservation of justice. ${ }^{68}$ Both Madison and Rawls contend that individuals must be ignorant of their specific long-term interests if they are to frame a fair constitution. Rawls's "original position" is hypothetical, however, while Madison thought history had provided, to use Rawis's phrase, a "veil of ignorance" behind which state constitutions should be framed.

onian Interpretation of the Equal Protection Doctrine, 91 YALE L.J. 1403 (1982).

65. Although Madison equated minority rights with those of property, procedural safeguards protect minority rights regardless of content.

66. J. MAdison, supra note 45, at 59 (M. Meyers ed. 1981) (remarks on Jefferson's draft of Kentucky constitution). Madison asserted that factions may be prevented by destroying the liberty essential to form them or by inducing homogenous opinions, THE Federalist No. 10, at 58 ( $\mathrm{J}$. Madison) (J. Cooke ed. 1961), and that the gradual concentration of property over time would eventually leave America with a vast majority uninterested in preserving property rights, see THE MIND OF THE FOUNDER, supra note 45 , at 59 . It was therefore necessary to guard against this danger in a document framed by a population which either owned property or had (at least in their own minds) the prospect of owning property. To preserve liberty, this document would have to be effective far into the future. Id.

67. J. RAwLs', A Theory OF Justice 17-22 (1971).

68. Id. at 11-22, 136-41. In Rawls' theory of justice, principles of justice analogous to constitutional principles are chosen by individuals in an "original position" where they do not know what their individual interests are. Analogously, Madison's individuals-in an historical rather than hypothetical original position-choose constitutional principles that protect both property and individual rights, because the bulk of them cannot predict where their different faculties for acquiring property will lead them. $I d$. at 11 . 


\section{Guarantee Clause}

State constitutions in Madison's day were framed to be difficult to amend. ${ }^{60}$ The prospective protection of the eventual minority therefore seemed possible. Even so, in the unstable arena of state politics, the historic compromises enshrined in state constitutions remain vulnerable to violation by majority factions and thus require a federal guarantee.

By interpreting the guarantee clause to require that states act consistently with their constitutions and laws, the federal courts do their part to guarantee that the protections of minorities in state constitutions which have been approved by Congress will be observed in practice. Without a federal guarantee, state governments, dominated by majority coalitions, could violate with impunity the provisions intended to protect minorities against state action. Under the rule of law interpretation of the guarantee clause, by contrast, the minority rights articulated in state constitutions and laws are guaranteed by a federal republic which is independent of the influence a state majority faction exerts against liberties inside the state. Moreover, the federal political marketplace is especially sensitive to the influence of minorities which, in turn, are better organized than the majority at the national level and which have an interest in monitoring the states' treatment of minorities. The guarantee of constitutional government in the small state republics by the overarching national republic ensures that minority liberties will be twice protected.

\section{IMPLICATIONS FOR REAPPORTIONMENT AND FEDERALISM}

The rule of law interpretation of the guarantee clause has important implications for the reapportionment cases and, more broadly, for American federalism.

\section{A. The Reapportionment Cases and Federalism}

Most theories of federalism take either a "states' rights" or a "nationalist" approach. Those who support "states' rights" tend to support state decisions in spite of their often prejudicial effects on minority rights. ${ }^{70}$

69. See G. WoOD, supra note 40, at 307-09 (state constitutions at time contained provisions against amendment by legislative act and thus were beyond reach of mere majorities); see also id. at 309-43 (detailed history and theory of state constitution-making between 1776 and 1787). For tables of the states' current amendment procedures, see THE BOOK OF THE STATES 1982-83, at 136-37 (1982).

70. See Bickel, The Supreme Court and Reapportionment, in REAPPORTIONMENT IN THE 1970s 57-58 (N. Polsby ed. 1971) (apportionment decisions constitutionally unjustified and politically unwise). For a historical presentation of the states' rights viewpoint pertaining to constitutional law in general, see The States Rights Debate: Antifederalism and the Constitution (A. Mason ed. 1972). For a discussion of reapportionment, see id. at 195. See also Mason, The Nature of Our Federal Union Reconsidered, 65 PoL. Scr. Q. 502 (1950) (reconsidering federalism from states' rights point of view). 
Those who support "nationalism," on the other hand, advocate federal review of state action according to uniform, national standards. ${ }^{\mathbf{7 1}}$

In Reynolds $v$. Sims, ${ }^{72}$ the Supreme Court imposed a uniform, national standard of "one man, one vote" on the representative institutions of state governments. ${ }^{73}$ Reynolds was a nationalist response to long-standing abuses of the kind Madison anticipated: Certain factions within the states had gained and maintained a stranglehold on state governments ${ }^{24}$ by effectively excluding other factions from equal participation in state politics, ${ }^{75}$ often in violation of the state's own constitution. ${ }^{76}$ This would seem an ideal situation for applying the rule of law interpretation of the guarantee clause proposed by this Note. The Court in Reynolds, however, took a

71. The "nationalist" point of view was articulated in the reapportionment cases themselves. See Reynolds v. Sims, 377 U.S. 533, 561-68 (1964) (presentation of court's unitary theory of representation and, by implication, its power to enforce it). For a theoretical article that supports a strong nationalist court, see Fiss, The Supreme Court, 1978 Term-Foreword: The Forms of Justice, 93 HARV. L. REv. 1 (1979).

72. 377 U.S. 533 (1964).

73. Id. at 583.

74. For typical discussions by the Court of the population changes that led to malapportionment, see Roman v. Sincock, 377 U.S. 695, 704-05 (1964); Maryland Comm. for Fair Representation v. Tawes, 377 U.S. 656, 664-67 (1964). The stranglehold on state government was usually made possible by the requirement that the state legislature, at some stage, approve reapportionment. See Tawes, 377 U.S. at 668-69 (approval of state legislature required before constitutional convention to bring about reapportionment could be convened).

75. For studies of the effect of apportionment patterns on policy outcomes in the states, see Dye, Malapportionment and Public Policy in the States, 27 J. PoL. 586 (1965); Hofferbert, The Relation Betueen Public Policy and Some Structural and Environmental Variables in the American States, 60 AM. Pol. SCI. Rev. 73 (1966); Jacob, The Consequences of Malapportionment: A Note of Caution, 43 Soc. ForCes 256 (1966). These studies all support the conclusion that patterns of state legislative apportionment have little if any effect on lawmaking in state legislatures. For a critique of these studies, see Bickel, The Effects of Malapportionment in the States-A Mistrial, in REAPPortionMENT IN THE 1970s, supra note 70, at 151. For an assessment of the effects of reapportionment on one southern state, see Sharkansky, Legislative Reapportioninent in Georgia: Changes in Voting Patterns and their Policy Implications, in ReAPPORTIONMENT IN GEORGIA 97 (B. Hawkins ed. 1970).

76. In Baker v. Carr, 369 U.S. 186 (1962), the Court noted that Tennessee did not reapportion between 1901 and 1961, id. at 192, although the state constitution required reapportionment at least every ten years, TENN. Const. art. 2, §§ 3-5. In Reynolds, the Court noted that, as of the time the suit began, there had been no reapportionment of seats in Alabama's legislature for over' 60 years, 377 U.S. at 570, although the state constitution required reapportionment every ten years, AlA. CoNST. art. IX, $\S \S 199-200$. The Court stated that the "[c]onsistent failure by the Alabama legislature to comply with state constitutional requirements as to the frequency of reapportionment and the bases of legislative representation resulted in a minority stranglehold on the State Legislature." Reynolds, 377 U.S. at 570 (citations omitted). In Lucas v. Colorado Gen. Assembly, 377 U.S. 713 (1964), the Court noted that "the Colorado Legislature has never complied with the state constitutional provision [Colo. CoNST. art. V, $\S 45$ ] requiring the conducting of a decennial state census in 1885 and every 10 years thereafter, and of course has never reapportioned seats . . . based upon such a census." Lucas, 377 U.S. at 723 n.9.

The applicability of Madisonian theory is not affected by the fact that the dominating faction in the state may not have constituted a numerical majority of a state's citizens. Madison discussed the domination by a majority faction or coalition, but Madisonian theory applies all the more strongly if the faction in control is a minority, since tyranny by a minority is arguably even more oppressive than tyranny by the majority. Indeed, Madison considered the overthrow of constitutional governments in the states by both minorities and majorities in his early proposal of a guarantee clause. See THE MIND OF THE Founder, supra note 45 , at 85 . 
different approach, criticized for its simplistic majoritarianism, which seemed irreconcilable with the adroitly designed checks on majority will and protections of minority rights at the heart of American constitutionalism. ${ }^{77}$ By setting a uniform standard, moreover, the Court forbade any state to experiment with the design of republican government, prohibited systems of representation that protected vulnerable minorities, and disallowed the adaptation of governmental institutions to a state's peculiar circumstances.

The Court's approach to the reapportionment cases involved massive federal intrusion into state politics and government. ${ }^{78}$ By drawing and redrawing legislative and congressional district boundaries, federal courts came to assume a central role in governing the states. This development, ironically, could take place only after the Court had swept aside the only clause in the Constitution, the guarantee clause, that bore squarely on the Constitution's requirements for representativeness in state governments. ${ }^{79}$

The proposed rule of law standard of this Note is more sensitive and direct than "one man, one vote," allowing instead the people of a state to choose the system of representation of their government, subject only to the general approval of Congress. The federal courts would then insure that each state government in practice lived up to the standards set down in that state's constitution and valid laws.

Federal courts could indeed have approached the leading reapportionment cases in this manner. Examining the reapportionment cases, it becomes clear that state legislatures had disregarded their state constitutions for up to sixty years by refusing to reapportion as state populations changed. ${ }^{\text {so }}$ The states involved, Tennessee, Alabama, and Colorado, each had constitutional provisions requiring representation according to population and periodic reapportionment. ${ }^{81} \mathrm{~A}$ federal judge acting under the rule of law interpretation of the guarantee clause would simply have ordered the state legislatures to reapportion in a manner consistent with their own state constitutions. ${ }^{82}$ While the nationalist viewpoint of the Su-

77. See A. Bickel, supra note 43, at 103-81; A. Bickel, Reform AND ConTINuITy 1-36 (1971); Neal, Baker v. Carr: Politics in Search of Law, 1962 Sup. CT. Rev. 252; Bork, supra note 25, at 19; R. Dixon, Democratic Representation 17, 267-71, 582-83 (1968).

78. Sep M. Shapiro, Law and Polttics in the Supreme Court: New Approaches to PoLITICAL JURISPRUDENCE 247-52 (1964) (criticism of reapportionment cases as intrusive in state politics and incompatible with federalism).

79. See supra p. 564 (discussing Baker v. Carr).

80. See supra note 76.

81. See supra note 76.

82. Those constitutions which embodied rigid formulas of representation presented a more difficult problem. Such formulas quickly became outdated as the population increased and its distribution changed. Moreover, the procedures for reapportioning representation were useless because they were under the control of the entrenched legislators. See, e.g., DEL. CoNST. of 1897, art. II, § 2, discussed in Roman v. Sincock, 377 U.S. 695, 698 (1964) (prohibiting changes from apportionment of 1897); 
preme Court led to the imposition of the legislative institutions prescribed by "one man, one vote," clause would leave the revision of state constitutional structures to Congress. $^{84}$

Such a division between judicial and legislative monitoring of state constitutions and their enforcement is appropriate because Congress is the most competent body to make the essentially political judgments involved in restructuring a state's constitution so as to provide for a republican form of government. ${ }^{85}$ The Court is better suited to review the enforcement of state constitutions after they are framed, rather than prescribe what their content should be. ${ }^{88}$

States might also wish to update state constitutions under congressional supervision. ${ }^{87}$ The arguably outmoded constitution of Colorado might have been reformed in a manner acceptable to Congress, for example, by amendment through statewide referendum. In Lucas v. Colorado General Assembly, ${ }^{88}$ however, the Court's adherence to the "one man, one vote" approach $^{80}$ led it to find unconstitutional a reasonable amendment to the Colorado constitution. ${ }^{80}$

WMCA, Inc. v. Lomenzo, 377 U.S. 648, 651-52 (1964) (New York constitution placed state constitutional amendment process in hands of malapportioned legislature).

83. See, e.g., Roman v. Sincock, 377 U.S. 695, 698-711 (1964) (requiring reapportionment according to uniform national standard); Maryland Comm. for Fair Representation v. Tawes, 377 U.S. 656, 669-70 (1964) (same).

84. Congress could choose to remand the reframing of an obsolete state constitution to a state constitutional convention representative of the people of the state. If Congress found state politics to be thoroughly corrupted by anti-republican influences, it might instead impose a constitution of its own choosing. Such drastic remedies would probably never be needed. Their existence, however, would serve as a strong incentive to tyrannical state factions to respect state constitutional protections of minorities already in place.

85. Congress is more competent to review political representation in the states because of its greater access to information and its lack of need to follow stare decisis or any one coherent set of principles. This flexibility is desirable when one must answer the many political questions involved in deciding whether a government is republican or not. Cf. supra note 13 (discussing Justice Woodbury's dissent in Luther). For a detailed discussion of the relative institutional competence of Congress and the Court in the context of the guarantee clause, see Scharpf, supra note 19, at 566-97.

86. See Pacific States Tel. \& Tel. Co. v. Oregon, 223 U.S. 118, 149-51 (1912); Luther v. Borden, 48 U.S. (7 How.) 48, 51-54 (1849) (Woodbury, J., dissenting).

87. States that attempted to amend their constitutions to provide for the permanent domination of a particular faction, however, would face, under this Note's proposal, intense congressional scrutiny. Such attempts at domination would closely approximate the monarchal and aristocratic innovations the Framers explicitly wished to forbid. Congress would clearly have the power to forbid such innovations under the rule of law interpretation of the guarantee clause. See THE FEDERALIST No. 43 (J. Madison).

88. 377 U.S. $713,717-19$ (1964).

89. The court in Lucas found that the state's constitutional amendments, even though approved by a large majority in the state, did not meet the uniform national standard. Id. at 734-38.

90. The amendment provided for reapportionment and a two-chambered legislature analogous to the federal House and Senate, and had been approved by a large majority of the state's voters. Id. at 734-38. 


\section{Guarantee Clause}

Reapportionment under the rule of law interpretation of the guarantee clause would not only have been more deferential to state sovereignty than the simple nationalist approach but also would have better protected the rights of minorities than a states' rights approach. The rule of law approach to reapportionment prohibits arbitrary violations of minority rights by tyrannical state factions but preserves the diversity of the states' rights approach by not imposing a single standard and by allowing each state to adapt its constitutional protections to its special circumstances. Because state constitutions are more easily amended than the federal constitution, state constitutional protections would also be more likely to remain contemporary under the rule of law approach ${ }^{22}$ through a process more democratic than noninterpretive judicial review. ${ }^{93}$ The possibility that some states will use the amendment process to discriminate against minorities is reduced by the role given to Congress under this Note's proposal: Congress could reject state constitutional amendments or legislation as unrepublican $^{24}$ and impose national standards when necessary to protect the rights of minorities. ${ }^{95}$

\section{B. The Autonomy of State Law}

The rule of law interpretation of the guarantee clause raises questions about the traditional distinction between federal and state law. The

91. Compare supra note 69 with U.S. Const. art. V.

92. This is significant because much of recent constitutional adjudication has sought to find 20th century values in an 18th century document. See, e.g., Roe v. Wade, 410 U.S. 113 (1973) (right of woman to obtain abortion in first trimester protected by Constitution); Griswold v. Connecticut, 381 U.S. 479 (1965) (right of married persons to use birth control protected by Constitution). The method of updating legal protections proposed here may be compared with a proposal to use the style of common law adjudication to keep constitutional law up to date. See G. CALABRESI, A Common LAw FOR THE AGE OF STATUTES 16-30 (1982).

93. See generally M. Perry, The Constitution, The Courts, and Human Rights 10 (1982) ("the legitimacy of noninterpretative review is the central problem of contemporary constitutional theory"). "Noninterpretive review" is review based not on any interpretation of the constitutional text, but on the derivation of law from other sources of normative values, e.g., the prevailing morality or the Court's subjective judgment. Interpretative review strives to ground itself in the language of the Constitution. Noninterpretive review raises problems in a democracy because adjudication not based on the Constitution resembles legislation by judges, who usually are neither elected nor accountable to the people. This Note proposes that federal judges enforcing the guarantee clause interpret state constitutions rather than engage in noninterpretive review. It may be that this approach could substitute to some extent for noninterpretive review to achieve the desirable evolution of constitutional law, but that question is outside the scope of this Note.

94. See supra pp. 565-66.

95. The federal guarantee of state constitutions may have implications for incorporation theory as well. Rather than seeking to protect against state abuses through Fourteenth Amendment incorporation of the bill of rights, the often stronger guarantees of state constitutions could be activated by federal guarantee of their enforcement within the state. Indeed, wherever the federal government seeks to protect minority rights without imposing a uniform, national standard, this Note's proposal may provide a solution to the dilemma posed by the current need to choose either a nationalist or states' rights perspective in resolving issues of federalism and the protection of minority rights. 
landmark case of Murdock $v$. City of Memphis ${ }^{08}$ has been read as requiring federal courts to take a state court's determinations of state law as final. ${ }^{27}$ In the dispute over state legislative districting that led to Reynolds $v$. Sims, ${ }^{83}$ for example, the Alabama state court acknowledged that the legislative actions involved in the suit were in violation of the state's constitution, but said it lacked the power to interfere with the exclusively legislative function of apportionment.99 When state courts refused to enforce the state constitutions on this state quasi-"political question" ground, granting federal judicial intervention in order to enforce the federal court's conflicting interpretation of the state constitution might seem to overrule a state court's determination of state law and thus violate the doctrine of Murdock.

Under this Note's proposal, federal courts should reverse state court rulings when necessary to vindicate the federal right to a republican form of government. If a citizen of a state, however, has a federal right that guarantees that his state government will act consistently with all its state laws, then virtually any state law may raise a federal question. Federal courts would have to interpret state law in order to determine whether some state action was consistent with it. There is, therefore, a fundamental tension between this Note's view of federalism and the autonomy of state law and state courts.

Such tensions are not unprecedented in federalism. In a line of cases beginning with Martin v. Hunter's Lessee, ${ }^{100}$ for example, the Supreme Court has ruled that a state court may not misconstrue its own law so as to manufacture independent and adequate state grounds for its decision, and thus evade federal review of a federal question. ${ }^{101}$ In these cases, the Supreme Court in effect overturns a state court's determination of state law in order to vindicate a federal right. The autonomy of state law must

96. 87 U.S. (20 Wall.) 590, 632-33 (1874) (Court's appellate jurisdiction does not extend to state court's decision incorrectly adjudicating a federal question if state court's judgment rests on adequate and independent state determination of state law).

97. See Hart, The Relations Between State and Federal Law, 54 Colum. L. Rev. 489, 503 (1954).

98. 377 U.S. $533,540-41$ (1964).

99. See Opinion of the Justices, 263 Ala. 158, 164, 81 So. 2d 881, 887 (1955); Opinion of the Justices, 254 Ala. 185, 187, 47 So. 2d 714, 717 (1950); see also Ex parte Rice, 273 Ala. 712, 712, 143 So. 2d 848, 848 (1962) (denial of injunction forbidding 1962 primary election absent reapportionment); Waid v. Pool, 255 Ala. 441, 442, 51 So. 2d 869, 870 (1951) (holding that lower courts properly denied injunctive relief because plaintiffs sought state judicial interference in legislative province). 100. 14 U.S. (1 Wheat.) 304 (1816).

101. See Ancient Egyptian Arabic Order of Nobles of the Mystic Shrine v. Michaux, 279 U.S. 737 (1929); Ward v. Board of County Comm'rs, 253 U.S. 17 (1920); Creswill v. Grand Lodge, Knights of Pythias, 225 U.S. 246 (1912); see also C. Wright, Federal CourTs 747-49 (1983) (discussing doctrine of independent and adequate state grounds). For a neglected historical argument that the Framers intended that the Supreme Court speak authoritatively on questions of state law as well as federal law, see 2 W. Grosskey, Polmitics And the Constitution in the History or THE UnIted States 23-26 (1953). 
therefore sometimes give way before the federal courts' mandate to enforce federal rights. Nonetheless, some step must be taken to preserve the autonomy of state law if all state laws potentially create federal rights.

This Note proposes that when hearing claims arising under the guarantee clause, federal courts review state law determinations only if the state court involved has made a "clear mistake" in interpreting its state law in a manner which results in its failure to perform its constitutionally imposed duties. ${ }^{102}$ In practice, such flawed rulings would probably result from the influence of powerful political factions on the state courts. Such influence is more likely to be effective at the state level than the federal because of the relative dependence of the state judiciaries on political arms of government. ${ }^{103}$ If a state court has clearly misread or refused to enforce the state constitution or laws, the parties involved have not received the protection due them under the state law, and therefore, the guarantee clause has been violated. A federal judge reversing a clear misconstruction of state law under the guarantee clause would thus be justifying federal intervention on grounds similar to those advanced in the line of cases following Hunter's Lessee. ${ }^{104}$ The "clear mistake" standard strikes a balance between the autonomy of state law and the vindication of guarantee clause rights. It provides adequate deference to state courts' particular expertise, without allowing that expertise to shield clear violations of the guarantee clause. Moreover, any harm stemming from the increased discretion of federal judges relative to their state counterparts would be outweighed by the rule of law gains from assuring that state officials observe the law under which they ought to govern.

\section{Conclusion}

This Note has offered a new theory of the guarantee clause. By interpreting the clause to guarantee the rule of law in the states through re-

102. The "clear mistake" standard of review in constitutional law received its classic treatment in Thayer, The Origin and Scope of the American Doctrine of Constitutional Law, 7 HaRv. L. REv. 129 (1893). But see A. Bickel, The Least Dangerous Branch 35-46 (1962) (criticizing Thayer).

103. See generally Neuborne, The Myth of Parity, 90 Harv. L. REv. 1105, 1105-30 (1977) (evaluation of political independence and other qualities of state judiciaries as compared with federal judiciary).

104. See supra note 101. Any claim that a state action violates that state's constitution or laws raises a genuinely federal question under this Note's proposed interpretation of the guarantee clause. Under the Note's proposal, however, the federal courts would accord the state court determination dispositive weight unless that determination was a clear mistake. Although guarantee clause rights are federally guaranteed, this Note argues they derive their content from state law. This is justified because state courts have special competence to interpret state law-as evidenced by the deference of federal courts to state courts in issues of state law in diversity cases. See, e.g., Day-Zimmerman, Inc. v. Challoner, 423 U.S. 3 (1975) (Texas federal court must apply Texas choice-of-law rules); Erie R.R. v. Tompkins, 304 U.S. 64 (1938) (federal courts to apply state law in diversity cases). Federal courts should defer to state court determinations as to the content of state law except when the state court is clearly mistaken. 
quiring that states observe their own constitutions and laws, the Note suggests the clause is a justiciable source of constitutional standards, and that those standards proceed from the fundamental and statutory law of the states themselves. By arguing that this interpretation amounts to the incorporation of state constitutional protections into the federal constitution, the Note advances a new theory of federalism that avoids the standardlessness of the states' rights view and the excessive nationalism of the current orthodoxy.

-Thomas A. Smith 